\title{
Knowledge and Attitude Regarding Crisis Management of Natural Disaster among People of Selected Rural Community in Kannur District kerala
}

\author{
Valsamma Cherian ${ }^{1}$, Senthilkumar T ${ }^{2 *}$, Shimjitha Zacariah ${ }^{3}$ and Vipin Sreenivasan ${ }^{3}$ \\ ${ }^{1}$ Professor, HOD-Department of Community Health Nursing, Lourde College of Nursing, Taliparamba, Kannur, Kerala, India \\ ${ }^{2}$ Principal, Lourde College of Nursing, Taliparamba, Kannur, Kerala, India
}

${ }^{3}$ Final Year B.Sc Nursing student, Lourde College of Nursing, Taliparamba, Kannur, Kerala, India

*Corresponding Author: Senthilkumar T, Principal, Lourde College of Nursing, Taliparamba, Kannur, Kerala, India.

Received: January 21, 2022; Published: February 05, 2022

DOI: $10.55162 /$ MCMS.02.019

\begin{abstract}
Background: The aim of the present study was conducted to assess the level of knowledge and attitude regarding crisis management of natural disaster among people of selected rural community at Kannur district.

Objectives: Assess the knowledge and attitude about the crisis management in natural disaster among local people. Find out the association between knowledge and attitude of people with selected demographic variables. Find out the correlation between knowledge and attitude regarding crisis management in natural disaster.

Setting and Sample: Study was conducted in 250 families at pattuvam Gram Panchayath, Taliparamba, Kannur, Kerala.

Materials \& Methods: Quantitative descriptive approach and cross-sectional design were used for this study and sample selected by convenient sampling technique. A self-structured knowledge questionnaire and attitude scale comprised of 10 items and 15 statements respectively.

Results: The study result shows that majority of samples were very good knowledge (81\%) and positive attitude towards crisis management on natural disaster.

Keywords: Knowledge; Attitude; Crisis management; Natural disaster
\end{abstract}

\section{Introduction}

A disaster is an unexpected occurrence or a natural calamity that causes considerable damage or deprivation of life. It is an event or fact that has untoward consequences happening in our human life. A disaster can occur during a short or long period of time. It also causes wide spread human, material, economic or environmental loss. Vulnerability is due to rapid and uncontrolled development of cities, persistence of widespread urban and rural poverty, and deterioration of the environment resulting from the misutilization of the natural resources, ineffective public policies and lagging investments in infrastructure [1].

Human activities take part in a major role in the recurrence and seriousness of disaster. A natural disaster is destruction in the balance of the environment. The individual factor rises the value in both belongings harm and deprivation of life. There are two types disaster ie, Manmade disaster and natural disaster. Natural disaster are floods, cyclones, draught, earthquake, thunder storms, heat waves etc. and the manmade disaster are food poisoning, epidemics, population, deforestation, environmental pollution etc [2].

In a disaster can cause physical injury, death or mental stress. Then people may lose their home, possession and community. Such stresses place you are at threat for emotional and physical health problems. Direct and indirect losses as a result of disaster. Disaster preparedness refers to measures taken to prevent or reduce the effect of disaster [3].

Citation: Senthilkumar T., et al. "Knowledge and Attitude Regarding Crisis Management of Natural Disaster among People of Selected Rural Community in Kannur District kerala”. Medicon Medical Sciences 2.3 (2022): 09-14. 
Knowledge and Attitude Regarding Crisis Management of Natural Disaster among People of Selected Rural Community in Kannur District kerala

Human have a managed disaster and a overview of our past experiences shows that management of disaster is not a new concept in ancient India, draughts where effectively managed through conventional water conservation method, which are still in use in certain part of country like Rajasthan. India is considered as a world's most disaster-prone country. Millions of people effected every year and economic losses causes by this disaster. Natural disasters are huge economic burden on development [4].

Need for the Study

The purpose of this research is to study and explore the importance of knowledge and attitude regarding crisis management of natural disaster events. A disaster is an unpredicted event which can overwhelm the capacity of the effected people to manage its input. Many people are occasionally exposed to natural disaster in their life and most disaster or more correctly hazards that lead to disaster cannot be prevented. However, their effect can be mitigated. Disaster management effort aim to reduce or avoid potential losses from hazards, so we can assure correct or appropriate help to victims of disaster and achieve rapid recovery [5].

The increasing impact of natural disaster one highly correlated to the increasing vulnerability of households and communities especially in developing countries. Hence the impact of any disastrous event could result in a immediate increase in poverty. This condition highlights the importance of disaster preparedness especially in Asia, where the most developing countries are located. Knowledge on disaster management is a important step towards disaster prepared families especially among rural community in developing countries.

According to grooves, individual have higher knowledge could become more aware about personnel responsibility in emergency management. Higher knowledge could move individual to more active state that is individuals are more likely to take action. Accordingly, this research evaluates the knowledge and attitude of rural people about the disaster management for community and about the challenges that need to be considered during the disaster response [6-7].

\section{Statement of the problem}

A study to assess the level of knowledge and attitude regarding crisis management of natural disaster among people of selected rural community in Kannur district, Kerala.

\section{Objectives of the study}

The objectives of the study are,

- $\quad$ Assess the knowledge and attitude about crisis management of natural disaster among local people.

- Find out the association between knowledge and attitude on crisis management of natural disaster and selected demographic variables.

- Find out the correlation between knowledge and attitude regarding crisis management of natural disaster.

\section{Hypotheses}

- There is a significant association between knowledge and attitude of crisis management of natural disaster and selected demographic variables.

- There is a significant correlation between knowledge and attitude regarding crisis management of natural disaster.

\section{Materials and Methods}

A quantitative approach was used for present study. A descriptive cross-sectional design were used to assess the level of knowledge and attitude regarding crisis management of natural disaster among people. Data collection tools are the procedures or instruments used by the researcher to measure the key variables in the research problem. The demographic details were collected using a struc- 
Knowledge and Attitude Regarding Crisis Management of Natural Disaster among People of Selected Rural Community in Kannur District kerala

tured baseline Proforma prepared by the investigator. The level of knowledge and attitude regarding crisis management of natural disaster among people were assessed using attitude and knowledge scale prepared by the investigator [8-10].

\section{Data collection process}

The purpose of the study, data collection methods and time duration were explained to subject for getting free and true responses. They were also giving assurance regarding the confidentiality of the information. Informed consent from the respondents prior to the data collection process. The purpose of the study was clearly explained and confidentiality of the data was assured to the samples. Subject who fulfils the sample selected from rural area by convenient sample technique. The data was collected on $31 / 12 / 2019$ to 02/1/2020 after obtaining ethical clearance from institutional ethical committee [11].

\section{Results}

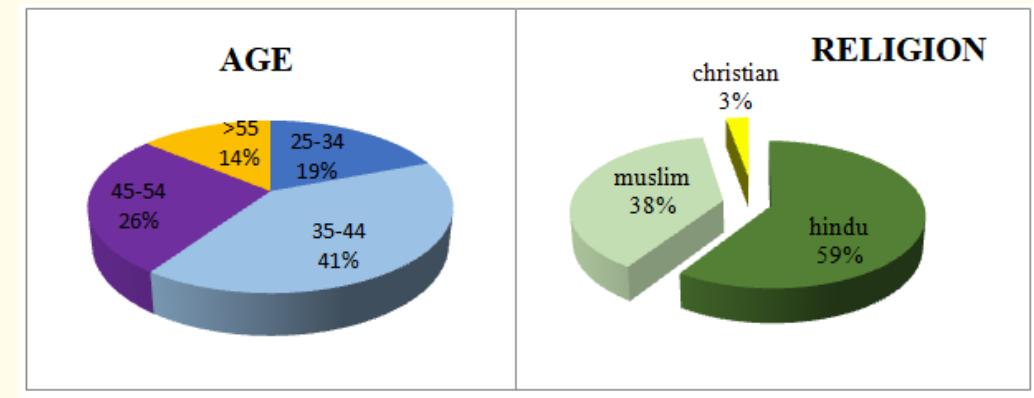

Figure 1: Distribution of respondents according to their Age and Religion.
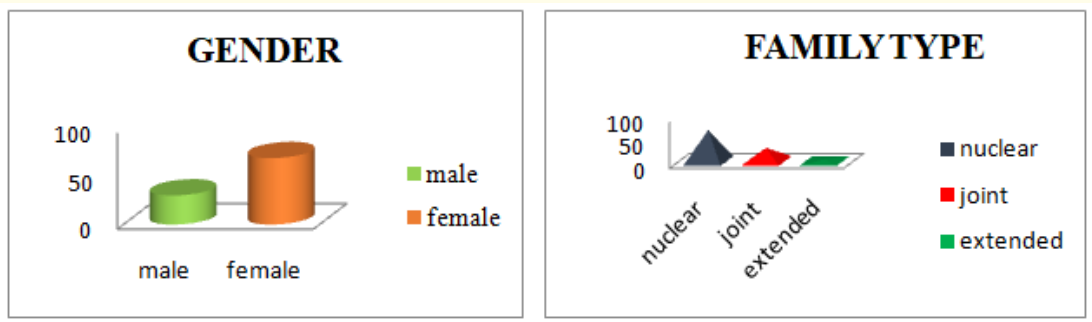

Figure 2: Distribution of respondents according to their Gender \& Family type.
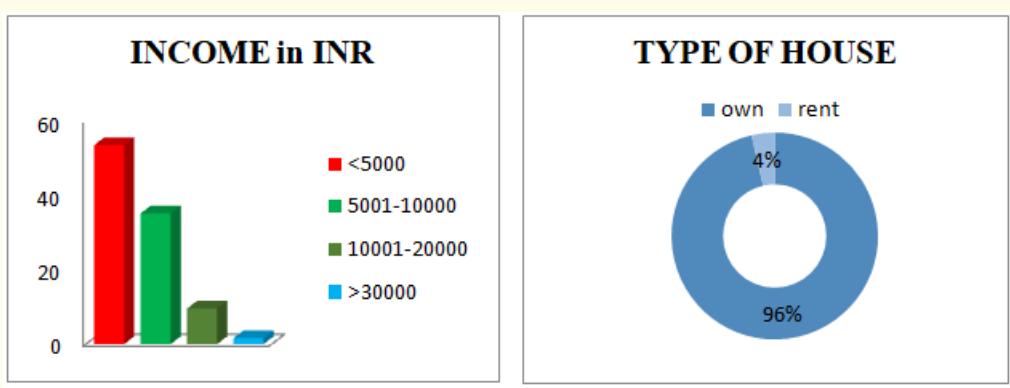

Figure 3: Distribution of respondents according to their income \& type of income. 
Knowledge and Attitude Regarding Crisis Management of Natural Disaster among People of Selected Rural Community in Kannur District kerala

\begin{tabular}{|c|c|c|c|c|}
\hline $\begin{array}{c}\text { Level of knowledge } \\
\text { regarding crisis manage- } \\
\text { ment }\end{array}$ & Range & Mean & Median & $\begin{array}{c}\text { Standard } \\
\text { Deviation }\end{array}$ \\
\cline { 2 - 5 } & $2-7$ & 7.208 & 8 & 1.68 \\
\hline
\end{tabular}

The maximum score is 10 and minimum score is 0 .

Table 1: Description on level of knowledge regarding management of natural disaster $n=250$.

The above table shows knowledge of 250 families regarding on crisis management of natural disaster. The mean, median, standard deviation of knowledge regarding crisis management 7.208, 8, 1.68 respectively. It reveals that most of the rural people had good knowledge regarding crisis management on natural disaster.

\begin{tabular}{|c|c|c|c|c|}
\hline \multirow{2}{*}{$\begin{array}{c}\text { Level of attitude } \\
\text { regarding crisis }\end{array}$} & Range & Mean & Median & $\begin{array}{c}\text { Standard } \\
\text { Deviation }\end{array}$ \\
\cline { 2 - 5 } management & $22-75$ & 59.66 & 64 & 13.17 \\
\hline
\end{tabular}

The maximum score is 75 and minimum score is 0 .

Table 2: Description on level of attitude regarding management of natural disaster $n=250$.

The above table shows the knowledge of the 250 families regarding attitude on crisis management of natural disaster. The mean, median, standard deviation of attitude regarding crisis management 59.66, 64, 13.17 respectively. It reveals that majority of the rural people had very good attitude regarding crisis management on natural disaster.

\begin{tabular}{|c|c|c|c|c|c|c|}
\hline \multirow{2}{*}{ S. No } & \multirow{2}{*}{ Variables } & \multicolumn{2}{|c|}{ Level of knowledge on Natural Disaster } & \multirow{2}{*}{$d f$} & \multirow{2}{*}{$X^{2}$} & \multirow{2}{*}{ Inference } \\
\hline & & $<$ Mean & $>$ Mean & & & \\
\hline 1. & $\begin{array}{l}\text { Age } \\
\text { a) } 25-34 \\
\text { b) } 35-44 \\
\text { c) } 45-54 \\
\text { d) }>55\end{array}$ & $\begin{array}{l}18 \\
40 \\
25 \\
20\end{array}$ & $\begin{array}{l}27 \\
60 \\
42 \\
11\end{array}$ & 3 & 4.47 & Significant \\
\hline 2. & $\begin{array}{l}\text { Gender } \\
\text { a) Male } \\
\text { b) Female }\end{array}$ & $\begin{array}{l}34 \\
69 \\
\end{array}$ & $\begin{array}{c}42 \\
105 \\
\end{array}$ & 1 & 0.561 & Not significant \\
\hline 3. & $\begin{array}{l}\text { Occupation } \\
\text { a) Government } \\
\text { b) Home maker } \\
\text { c) Self occupa- } \\
\text { tion } \\
\text { d) Daily wager }\end{array}$ & $\begin{array}{c}15 \\
66 \\
18 \\
5\end{array}$ & $\begin{array}{c}9 \\
87 \\
34 \\
16\end{array}$ & 3 & 8.247 & Significant \\
\hline 4. & $\begin{array}{l}\text { Income in INR } \\
\text { a) }<5000 \\
\text { b) } 5001-10000 \\
\text { c) } 10001-20000 \\
\text { d) } 20001-30000 \\
\text { e) }>30000\end{array}$ & $\begin{array}{c}56 \\
42 \\
7 \\
1 \\
0 \\
\end{array}$ & $\begin{array}{c}79 \\
46 \\
15 \\
3 \\
1\end{array}$ & 4 & 3.2919 & Not significant \\
\hline 5. & $\begin{array}{l}\text { Type of house } \\
\text { a)Own } \\
\text { b)Rent }\end{array}$ & $\begin{array}{c}104 \\
1\end{array}$ & $\begin{array}{c}142 \\
3\end{array}$ & 1 & 8.189 & Significant \\
\hline
\end{tabular}

Table 3: Description on association between knowledge regarding crisis management with selected demographic variables. $n=250$ 
Knowledge and Attitude Regarding Crisis Management of Natural Disaster among People of Selected Rural Community in Kannur District kerala

The above table shows that, there is no significant association between level of knowledge and gender and income. There for research hypotheses "There is a significant association between knowledge on crisis management of natural disaster and selected demographic variables" was accepted for the variables include age, occupation, type of house.

\begin{tabular}{|c|c|c|c|c|c|c|}
\hline \multirow{2}{*}{ S. No } & \multirow{2}{*}{ Variables } & \multicolumn{2}{|c|}{ Level of attitude on Natural Disaster } & \multirow{2}{*}{$d f$} & \multirow{2}{*}{$X^{2}$} & \multirow{2}{*}{ Inference } \\
\hline & & $<$ Mean & $>$ Mean & & & \\
\hline 1. & $\begin{array}{l}\text { Age } \\
\text { a) } 25-34 \\
\text { b) } 35-44 \\
\text { c) } 45-54 \\
\text { d) }>55\end{array}$ & $\begin{array}{l}19 \\
25 \\
28 \\
14\end{array}$ & $\begin{array}{l}27 \\
75 \\
39 \\
23\end{array}$ & 3 & 6.698 & Significant \\
\hline 2. & $\begin{array}{l}\text { Gender } \\
\text { a) Male } \\
\text { b) Female }\end{array}$ & $\begin{array}{l}28 \\
60\end{array}$ & $\begin{array}{c}49 \\
113\end{array}$ & 1 & 0.07 & Not significant \\
\hline 3. & $\begin{array}{l}\text { Occupation } \\
\text { a) Government } \\
\text { b) Home maker } \\
\text { c) Self occupation } \\
\text { d) Daily wager }\end{array}$ & $\begin{array}{l}09 \\
48 \\
25 \\
03\end{array}$ & $\begin{array}{c}14 \\
107 \\
26 \\
18\end{array}$ & 3 & 9.665 & Significant \\
\hline 4. & $\begin{array}{l}\text { Income in INR } \\
\text { a) }<5000 \\
\text { b) } 5001-10000 \\
\text { c) } 10001-20000 \\
\text { d) } 20001-30000 \\
\text { e) }>30000\end{array}$ & $\begin{array}{l}45 \\
31 \\
13 \\
02 \\
01\end{array}$ & $\begin{array}{l}77 \\
66 \\
12 \\
03 \\
00\end{array}$ & 4 & 5.207 & Not significant \\
\hline 5. & $\begin{array}{l}\text { Type of house } \\
\text { a) Own } \\
\text { b) Rent }\end{array}$ & $\begin{array}{l}84 \\
03\end{array}$ & $\begin{array}{c}157 \\
06\end{array}$ & 1 & 3.192 & Not Significant \\
\hline
\end{tabular}

Table 4: Description on association between attitude regarding crisis management with selected demographic variables.

The above table shows that, there is no significant association between level attitude and gender income, type of house. There for research hypotheses "There is a significant association between attitude on crisis management of natural disaster and selected demographic variables" was accepted for the variables include age and occupation.

\begin{tabular}{|c|c|c|c|c|}
\hline \multirow{2}{*}{$\begin{array}{c}\text { Mean value of } \\
\text { Variables }\end{array}$} & Knowledge & Attitude & r value & Inference \\
\cline { 2 - 5 } & 7.208 & 59.66 & 0.0441 & Not Significant \\
\hline
\end{tabular}

Table 5: Correlation between knowledge and attitude regarding crisis management.

The above table shows correlation value between knowledge and attitude $(r=0.0441)$, which is not significant. Hence the research hypothesis "There is a significant correlation between the levels of knowledge and attitude regarding crisis management of natural disaster" was rejected and null hypothesis was accepted.

\section{Conclusion}

The analysed data shows that mean knowledge score was 7.208 and mean attitude score was 59.66. It reveals that majority of the rural people had good knowledge and very good attitude towards crisis management on natural disaster. There is a significant association between knowledge and age occupation and type of house. There is a significant association between attitude and age \& occupa- 
Knowledge and Attitude Regarding Crisis Management of Natural Disaster among People of Selected Rural Community in Kannur District kerala

tion of the rural people. Also, study finding reveals that negative correlation between knowledge and attitude.

\section{Nursing implications}

The findings of the research study will help to think and implement several possible strategies in the nursing practice, nursing education, nursing research and nursing administration.

\section{Acknowledgement}

The authors acknowledged all participants for taking part in this survey.

\section{Source of Funding}

Self-funded project.

\section{Conflict of Interest}

The authors declare that no conflict of interest.

\section{References}

1. El-Hosany WA., et al. "Knowledge and Awareness of Disaster Preparedness among Faculty of Nursing Members: Designing of Disaster Management Guidelines". Conference: The 6th International Scientific Conference "Integration in Health Care”. Ismailia, Egypt (2017).

2. Ganpatrao JS. "Knowledge and practices of school teacher regarding disaster management". International Journal of Health System and Disaster Management 2 (2014): 98-102.

3. Tuladhar G., et al. "Disaster risk reduction knowledge of local people in Nepal”. Geo-environmental disasters 2 (2015): 5.

4. Ahayalimudin., et al. "Disaster management: a study on knowledge, attitude and practice of emergency nurse and community health nurse". BMC Public Health 12 (2012): A3.

5. Marskole P., et al. "A study to assess awareness on disaster management among school going children in Gwalior (M.P.)". International Journal of Community Medicine and Public Health 5.4 (2018): 1371-1375.

6. Naser WN and Saleem HB. "Emergency and disaster management training; knowledge and attitude of Yemeni health professionals- a cross-sectional study”. BMC Emergency Medicine 18.1 (2018): 23.

7. Okoli Al Chukwuma. "Disaster Management and National Security in Nigeria: The Nexus and the Disconnect". International Journal of Liberal Arts and Social Science 2 (2014: 1.

8. Reshma V., et al. "A descriptive survey to assess the incidence of Health Indicators among the public at selected area, Thrissur". Community and Public Health Nursing 1.2 (2016).

9. Aghaei N., et al. "Strategies for disaster risk reduction education: A systematic review". Journal of Education and Health Promotion 2.7 (2018): 98.

10. Kanyasan., et al. "Implementation of disaster risk reduction and management policies in a school setting in Lao PDR: a case study". Tropical Medicine and Health 46 (2018): 42.

11. Wang J. "Study on the context of school-based disaster management". International Journal of Disaster Risk Reduction 19 (2016): 224-234.

Volume 2 Issue 3 March 2022 (C) All rights are reserved by Senthilkumar T., et al. 